\title{
SORPTION AND DESORPTION OF AMETRYN IN DIFFERENT TYPES OF SOILS
}

\author{
SORÇÃO E DESSORÇÃO DO AMETRYN EM DIFERENTES TIPOS DE SOLOS
}

\begin{abstract}
Alanna Oliveira CORTEZ ${ }^{1}$; Paulo Sérgio Fernandes das CHAGAS ${ }^{2}$; Tatiane Severo SILVA ${ }^{2}$; Daniel Valadão SILVA ${ }^{3}$; Claudia Daianny Melo FREITAS ${ }^{4}$; Juliana de Paiva PAMPLONA ${ }^{4}$; Hélida Campos de MESQUITA ${ }^{5}$; Matheus de Freitas SOUZA ${ }^{6}$

1. Mestre em Ambiente, Tecnologia e Sociedade, Programa de Pós Graduação em Ambiente, Tecnologia e Sociedade, UFERSA, Mossoró, RN, Brasil; 2. Doutorando em Fitotecnia, Programa de Pós graduação em Fitotecnia, UFERSA, Mossoró, RN, Brasil. tatiane.severosilva@gmail.com; 3. Professor, Doutor, Universidade Federal Rural do Semi-Árido, UFERSA, Mossoró, RN, Brasil; 4. Mestre em Fitotecnia, Programa de Pós graduação em Fitotecnia, UFERSA, Mossoró, RN, Brasil; 5. Professora, Mestre, do Instituto Federal de Educação, Ciência e Tecnologia do Rio Grande do Norte (IFRN), Campus Apodi, RN. 6. Doutor em Fitotecnia, Programa de Pós graduação em Fitotecnia, UFERSA, Mossoró, RN, Brasil.
\end{abstract}

\begin{abstract}
Knowledge of factors related to the dynamics of herbicides in the environment is of fundamental importance to predicting the behavior of herbicides in soils with different attributes, to select appropriate dosages, as well as to avoid harmful effects on the environment and subsequent crops. The objective of this work was to evaluate the sorption and desorption of ametryn in seven soils with different attributes. Initially, the equilibrium time was determined by the "Batch Equilibrium". Then, it was performed the sorption test with different concentrations $\left(0.5 ; 1 ; 2 ; 4 ; 8 ; 16 ; 24\right.$ and $\left.32 \mathrm{mg} \mathrm{L}^{-1}\right)$ of ametryn in $0.01 \mathrm{~mol} \mathrm{~L}^{-1}$ $\mathrm{CaCl}_{2} .10 \mathrm{~mL}$ of these solutions were added to samples of $2.00 \mathrm{~g}$ of each soil, remaining under rotary shaking for 4 hours. After centrifugation and filtration, the ametryn concentration in the supernatant was determined by high-performance liquid chromatography. Desorption was evaluated using the tubes containing $16 \mathrm{mg} \mathrm{L}^{-1}$ prior to sorption testing. The results indicated that the sorption and desorption of ametryn depend on the physicochemical attributes of the soil. Sorption was higher in soils with high organic matter content and high ion exchange capacity, while desorption was inversely proportional to sorption.
\end{abstract}

KEYWORDS: Carryover. Chemical control. Herbicide. Weed.

\section{INTRODUCTION}

Brazil is the second largest agricultural producer in the world (FAO, 2017) and one of the countries that most use agricultural pesticides to control pests, diseases, and weeds. Among agrochemicals used in crops, herbicides represent approximately $69 \%$ of the total phytosanitary products marketed in the country (SINDIVEG, 2019). This fact is related to factors such as practicality, efficiency and lower cost provided by the chemical control of weeds (ALBUQUERQUE et al., 2016).

The herbicides can be applied in the post and pre-emergence of weeds. An example of herbicide applied in the two modalities is the ametryn [2-(ethylamino)-4-isopropylamino-6methyl-thio-s-triazine]. This herbicide is widely used in corn, sugarcane, coffee, cassava, and pineapple plantations for the control of mono and dicotyledonous species (AGROFIT, 2019; STIPIČEVIĆ et al., 2015). The ametryn belongs to the chemical group of the triazines, is a weak base $(\mathrm{pKa}=4.1)$, with a water solubility of $200 \mathrm{mg} \mathrm{L}^{-1}$, and octanol/water partition coefficient ( $\log$ Kow $=$
2.63) (PPDB, 2019). However, frequent and inappropriate use of herbicides may decrease their efficiency in controlling and contaminate environmental resources, such as surface and groundwater (MARTINAZO et al., 2011).

Regardless of the application method (pre or post-emergence), the herbicides reach the soil, so for safe applications of this agrochemical, it is necessary to know its behavior in the soil. Once in the soil, herbicides can undergo different processes. Sorption and desorption are examples and define the amount of a herbicide available in the soil solution (DOS SANTOS et al., 2018). In the soil solution, the herbicides can be absorbed by plants, promoting weed control. However, under high rainfall conditions, the herbicide can leach and contaminate water resources (PASSOS et al., 2019; FARIA et al., 2018). For example, triazine herbicides (similar to ametryn) have been reported in groundwater worldwide (JACOMINI et al., 2009; BOHN et al., 2011; JIN; PELDSZUS et al., 2012; ALI et al., 2016).

Sorption and desorption occur with different intensity, and the physical and chemical characteristics of the adsorbent (soil) and adsorbate 
(herbicide) are the factors that determine the intensity with which they occur in the soil. In Brazil, the soils present a great diversity as to their physicochemical properties, and therefore the sorption and desorption of an herbicide can suffer great variation. Thus, conducting studies that aim to estimate the adsorption capacity of different soils are essential to reduce the environmental contamination caused by the application of herbicides. In the Brazilian Northeast, the chemical and mineralogical characteristics are different from those observed in regions of tropical climate. Generally, in the Brazilian Northeast in semi-arid conditions, the soils are less weathered, have alkaline $\mathrm{pH}$, with low organic carbon concentration and often have high salt concentration; therefore, the behavior of the herbicides may be different compared to the tropical and subtropical regions of Brazil.
Crops such as sugarcane, corn, cassava, and pineapple are cultivated in extensive areas in northeastern Brazil, and these areas are subject to the ametryn application for weed management. Given the need to know better the behavior of ametryn in Northeastern soils to reduce negative impacts on the environment, a study involving a greater amount of soils of this region is necessary. Thus, the objective of this study was to evaluate the influence of physical-chemical attributes of different Northeastern soils on sorption and desorption of the ametryn.

\section{MATERIAL AND METHODS}

The experiment was carried out in the laboratory, using seven samples of soils collected at depths of 0 to $20 \mathrm{~cm}$ in different locations, close to sugarcane, cassava or maize cultivations, but with no history of ametryn application (Table 1).

Table 1. Physicochemical attributes of soils used to evaluate ametryn sorption

\begin{tabular}{|c|c|c|c|c|c|c|c|}
\hline \multirow{2}{*}{ Soils } & \multirow{2}{*}{ Abbreviation } & $\mathrm{pH}$ & CEC & $\mathrm{OM}$ & Sand & Silt & Clay \\
\hline & & \multicolumn{6}{|c|}{$\left(\mathrm{H}_{2} \mathrm{O}\right) \mathrm{cmol}_{\mathrm{c}} \mathrm{dm}^{-3} \mathrm{dag} \mathrm{kg}^{-1}$} \\
\hline Gleysol & $\mathrm{G}$ & 3.9 & 15.92 & 2.04 & 50 & 28 & 22 \\
\hline Red Argisol & PV & 4.2 & 12.63 & 1.94 & 49 & 8 & 43 \\
\hline Red-Yellow Latosol & LVA & 5.0 & 9.09 & 1.31 & 63 & 11 & 26 \\
\hline Argisol Red Dystrophic Latosol & LVDA & 4.3 & 5.03 & 1.12 & 77.6 & 2.4 & 20 \\
\hline Espodosol carbic duric & EKo & 5.1 & 6.16 & 1.12 & 72 & 14 & 14 \\
\hline Ferrichumiluvic Espodosol & ESK & 4.5 & 9.39 & 0.94 & 85.2 & 2.3 & 12.4 \\
\hline Typical Dystrophic Yellow Latosol & LADT & 3.6 & 3.75 & 0.44 & 67.7 & 0.6 & 31.7 \\
\hline
\end{tabular}

The analyzes carried out at the Soil Fertility and Plant Nutrition Laboratory of the Universidade Federal Rural do Semi-Árido UFERSA, according to the methodology of the Silva (2009). pH: Hydrogenionic potential; CEC: Cation exchange capacity; OM: Organic matter.

The equilibrium time for the sorption and desorption processes of ametryn in soils was determined by the batch equilibrium method according to OECD (2000). For the equilibrium time, a solution was prepared with concentration of $10 \mathrm{mg} \mathrm{L}^{-1}$ from a stock solution of $1,000 \mathrm{mg} \mathrm{L}^{-1}$ prepare in $0.01 \mathrm{~mol} \mathrm{~L}^{-1} \mathrm{CaCl}_{2}$ solution. Then, 10.0 $\mathrm{mL}$ of this solution was added in tubes containing $2.00 \mathrm{~g}$ of soil. These were placed under constant stirring at 8 different times $(0.5,1,2,4,8,12,16,24$ hours) at $25^{\circ} \mathrm{C} \pm 2$. After stirring, the samples were centrifuged at $3500 \mathrm{rpm}$ for seven minutes. Part of the supernatant was filtered on a Millipore filter with $0.22 \mu \mathrm{m}$ PTFE membrane, for further analysis by high-performance liquid chromatography (HPLC).
For the sorption, working solutions were prepared from stock solution, at concentrations of $0.5 ; 1 ; 2 ; 4 ; 8 ; 16 ; 24$ and $32 \mathrm{mg} \mathrm{L}^{-1}$ of ametryn in $0.01 \mathrm{~mol} \mathrm{~L}^{-1} \mathrm{CaCl}_{2}$. From these solutions were added $10.0 \mathrm{~mL}$ in polypropylene tubes containing $2.00 \mathrm{~g}$ of soil. These tubes were then placed under stirring at room temperature for 4 hours (previously determined in the equilibrium time). After stirring, the samples were centrifuged at $3500 \mathrm{rpm}$ for seven minutes. The supernatant was removed and filtered in a Millipore $0.22 \mu \mathrm{m}$ filter for further chromatographic analysis.

All the supernatant present in the tubes used in the sorption test were removed. After this procedure, the desorption experiments were performed from the addition of $10 \mathrm{ml}$ of the 
herbicide-free $0.01 \mathrm{~mol} \mathrm{~L}^{-1} \mathrm{CaCl}_{2}$ solution in the tubes. Subsequently, the tubes were subjected to constant stirring. The experiment was repeated three times at different times 12, 24 and 36 hours. In each time the supernatant was centrifuged and filtered with $0.22 \mu \mathrm{m}$ filters directly into $1.5 \mathrm{~mL}$ vials and subsequently subjected to HPLC analysis.

The quantification of ametryn was performed in a high-performance liquid chromatography system coupled to a mass spectrometer (nexera model X2 SPD-M30A). The chromatographic conditions for the analysis were mobile phase composed of water and acetonitrile at a ratio of $30: 70(\mathrm{v} / \mathrm{v})$, with a flow of $0.3 \mathrm{~mL} \mathrm{~min}^{-1}$, an injection volume of $3 \mu \mathrm{L}$ and a wavelength of $254 \mathrm{~nm}$. The retention time of ametryn under these conditions was approximately one minute. The quantification was performed by the external calibration method. Identification, by retention time, was performed by comparison with the analytical standard of ametryn.

Then, the amount of herbicide sorbed to the soil (Cs) in $\mathrm{mg} \mathrm{kg}^{-1}$ was calculated by the difference between the amount of standard solution initially added to the soil (Cp) in $\mathrm{mg} \mathrm{L}^{-1}$ and the amount found in the equilibrium solution $(\mathrm{Ce})$ in $\mathrm{mg} \mathrm{L}^{-1}$.
With the values of $\mathrm{Ce}$ and $\mathrm{Cs}$, a Freundlich equation $\left(\mathrm{Cs}=\mathrm{Kf} \mathrm{Ce}^{1 / n}\right)$ was fitted to obtain the sorption coefficients, where $\mathrm{Kf}$ and $1 / \mathrm{n}$ are empirical constants representing the sorption capacity and intensity, respectively. The amount of the desorbed ametryn was calculated by the difference between the concentration of the herbicide in the soil, before the desorption stages, and the concentration in the solution analyzed after each interval. Subsequently, the desorption (\%) was calculated for each time interval (12, 24 and 36 hours).

The analyzes were performed with three replicates and triplicate. Pearson's correlation was performed between the physical-chemical characteristics of the soils and sorption coefficient (Kf), by the t-test at 1 and $5 \%$ of significance.

\section{RESULTS AND DISCUSSION}

The time required to reach the ametryn sorption equilibrium was 30 min for the seven soils (Figure 1). This time was defined based on the time when there was no further variation of the herbicide concentration in the supernatant solution. However, the soils were maintained for 4 hours to ensure that equilibrium had been reached in all treatments.

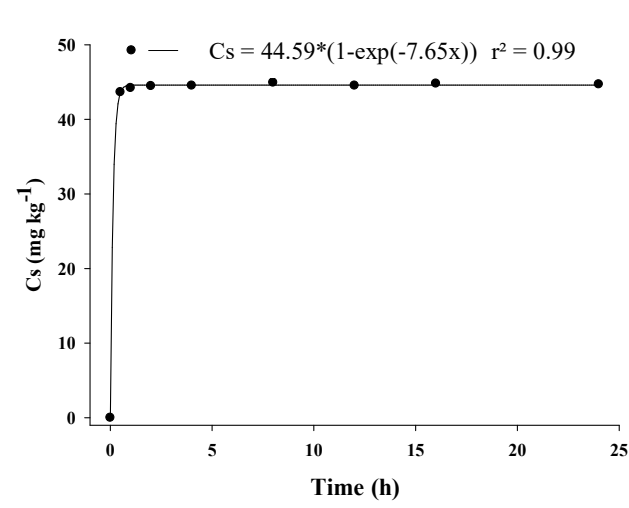

A

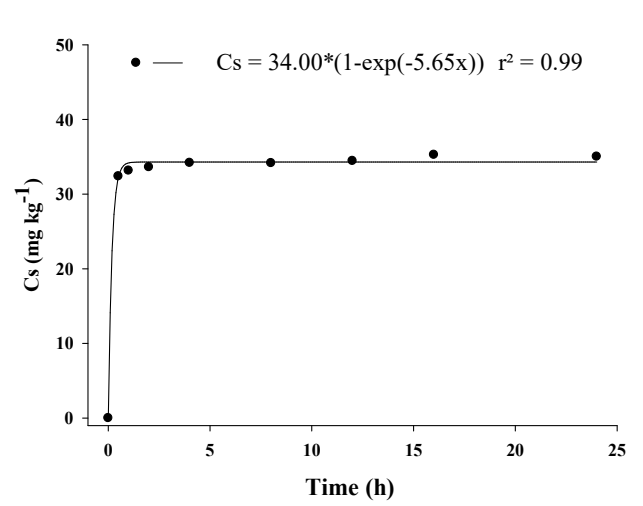

B

C

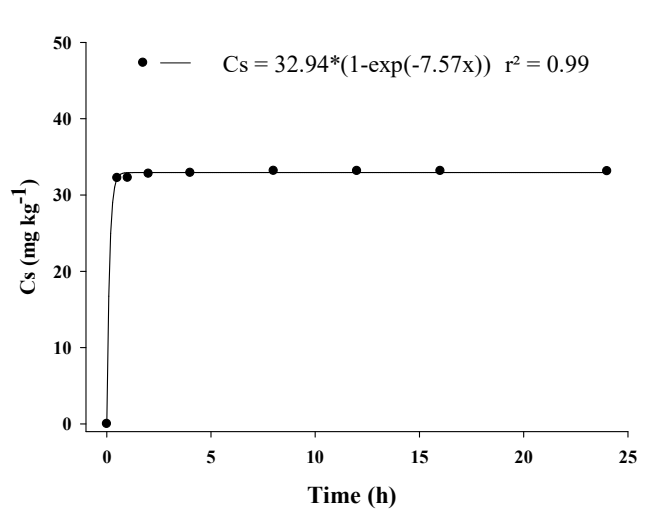

D

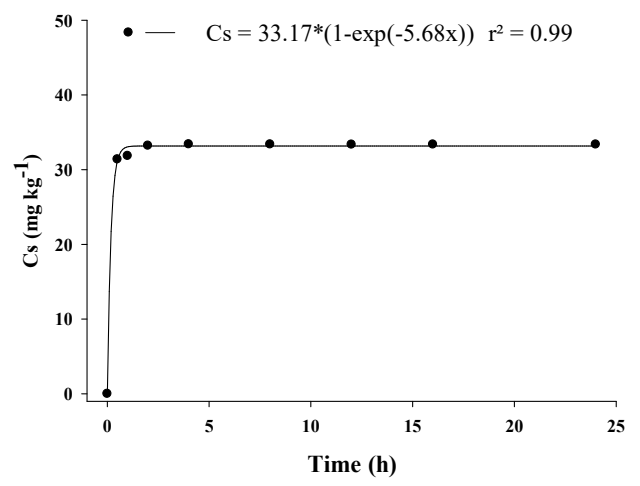




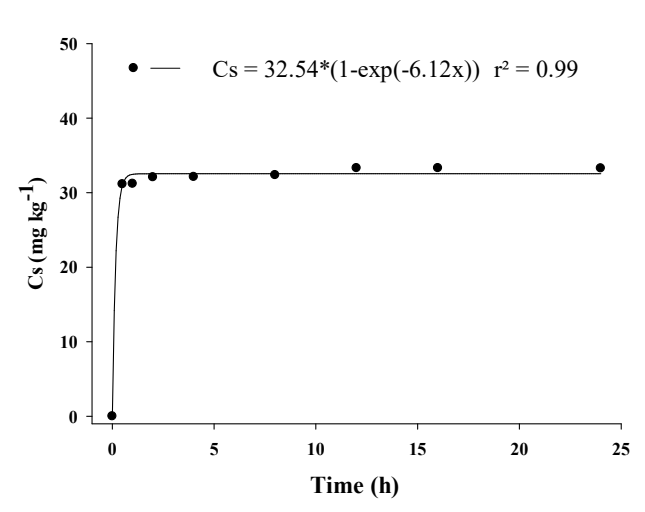

$\mathbf{E}$

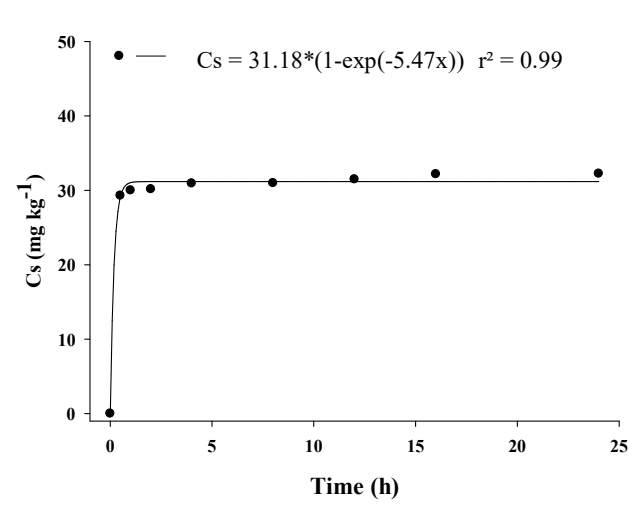

F

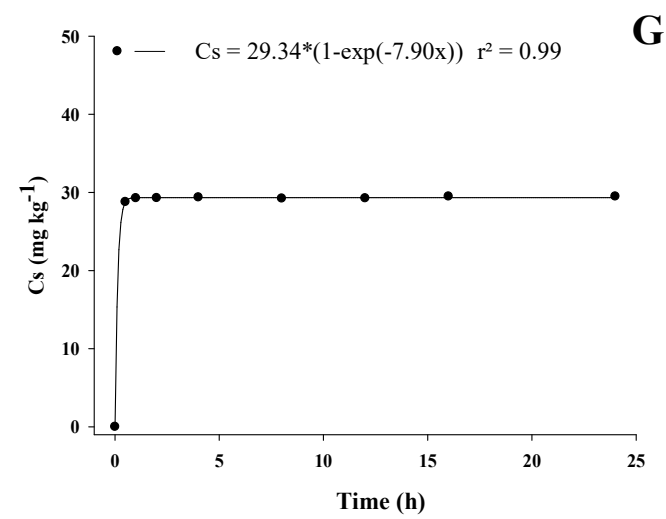

Figure 1. Estimates of the sorption kinetics curves as a function of the agitation time for ametryn in different soils: G (A), PV (B), LVA (C), LVDA (D), EKo (E), ESK (F) and LADT (G).

The Freundlich sorption isotherms for ametryn in the seven soils are shown in Figure 2. The models are well adjusted to the data, with high coefficients of determination (0.99). The parameter $1 / \mathrm{n}$ presented values smaller than 1 , varying from 0.81 to 0.97 . This fact characterizes the isotherms as type $\mathrm{L}$, non-linear and concave curve in relation to the abscissa, indicating that the availability of adsorption sites in the soil reduces when the herbicide concentration increases in the solution (FALONE; VIEIRA, 2004). The results observed in this working demonstrated a similar behavior with other studies which reported the adequacy of the Freundlich models to describe the ametryn sorption in soils (ANDRADE et al., 2010; SILVA et al., 2012).

The sorption coefficient (Kf) value ranged from 1.92 to 22.79 (Table 2). The lowest value of Kf was observed for LADT. Sandy texture $(67,7 \%)$, low organic matter content $\left(0.44 \mathrm{dag} \mathrm{kg}^{-1)}\right.$ and low ionic exchange capacity (CEC) $\left(3.75 \mathrm{cmol}_{\mathrm{c}} \mathrm{dm}^{-3}\right)$ of this soil can explain the low sorption of ametryn. The low sorption in this soil represent a high risk for environmental contamination, manly in an area where high rainfall rate occurs after ametryn application. In this condition, a higher amount of ametryn in soil solution can be leaching until deeper layers of soil, contaminating groundwaters (SILVA et al., 2012; PASSOS et al., 2019).

The G (22.70) and PV (6.42) showed the highest values for $\mathrm{Kf}$ (Table 2). By being one weak base ( $\mathrm{pKa}=4.1)$, depending on the $\mathrm{pH}$ of the soil, ametryn may exist on its neutral or protonated form. Ametryn shows higher adsorption rate at less acid $\mathrm{pH}$. At $\mathrm{pH}$ range 3.9 for $\mathrm{G}$ and 4.2 for $\mathrm{PV}$, with $\mathrm{pH}$ value is close to the $\mathrm{pKa}$ value, indicates that less of the herbicide is active in soil solution. There is a conversion of positively charged species to neutral ones, consequently, there is an increase in adsorption rate (SCHEEL; TARLEY, 2017). These soils have the highest organic matter content compared to the others studied soils (Table1). Studies have demonstrated that the organic matter is the soil attribute with the highest importance for sorption of organic pollutants (DOS SANTOS et al., 2018; FARIA et al., 2018). For example, in several programs that aim decontaminate soils exposure to herbicides application, the organic compounds, such as biochar, are an efficiency to adsorb the molecules, reducing the amount of herbicide in the soil solution (MENDES et al., 2017). 


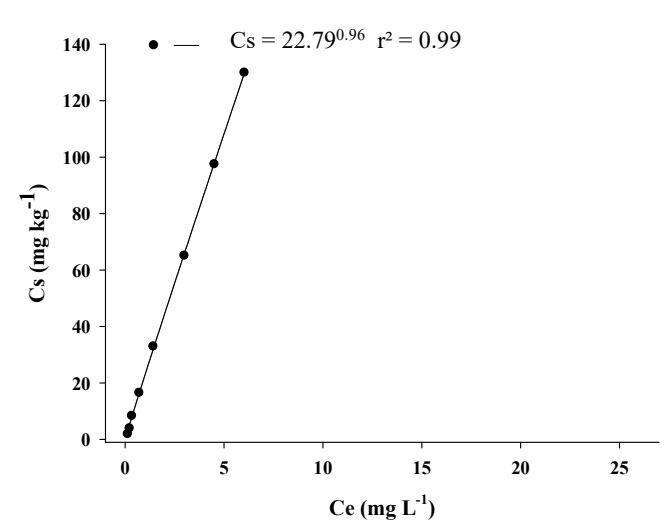

A

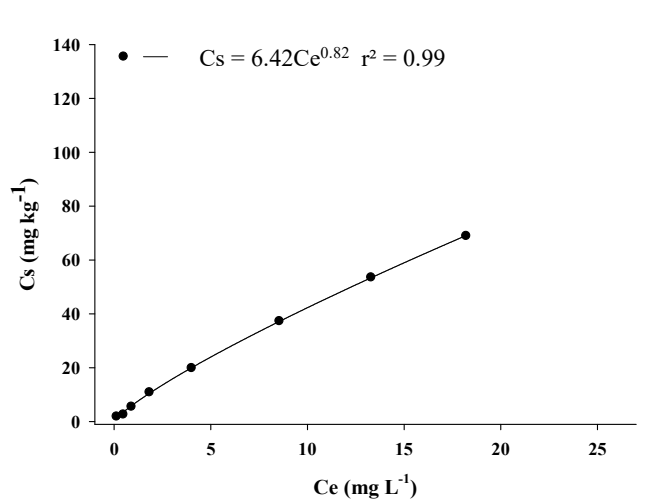

B

$\mathbf{C}$
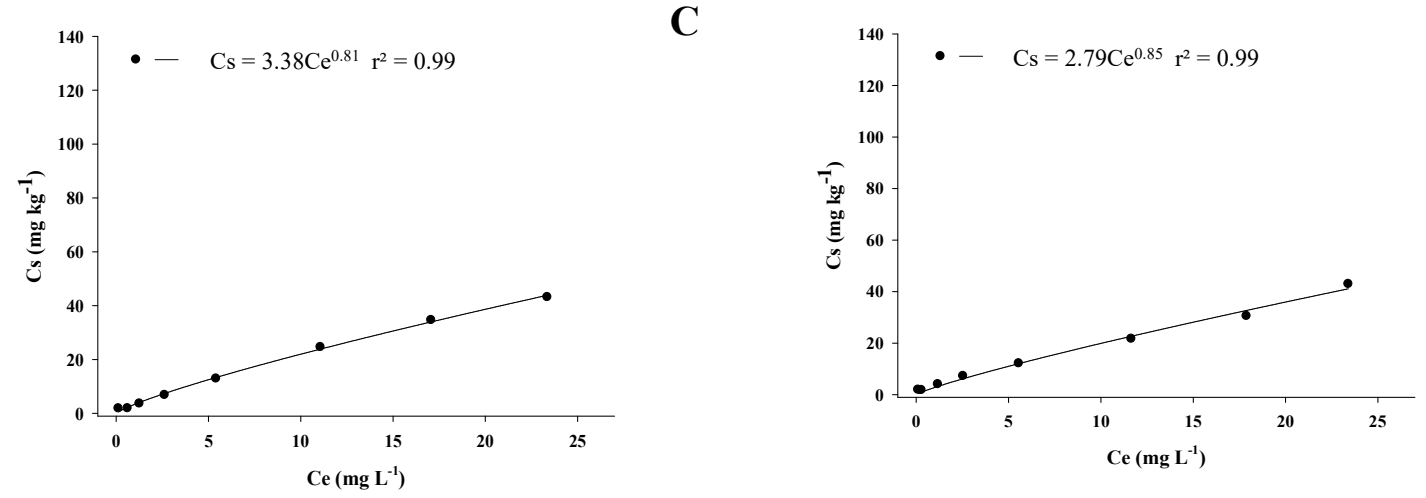

D

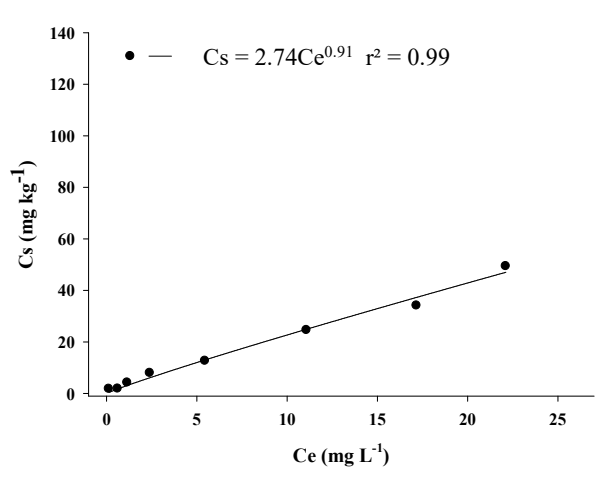

$\mathbf{E}$

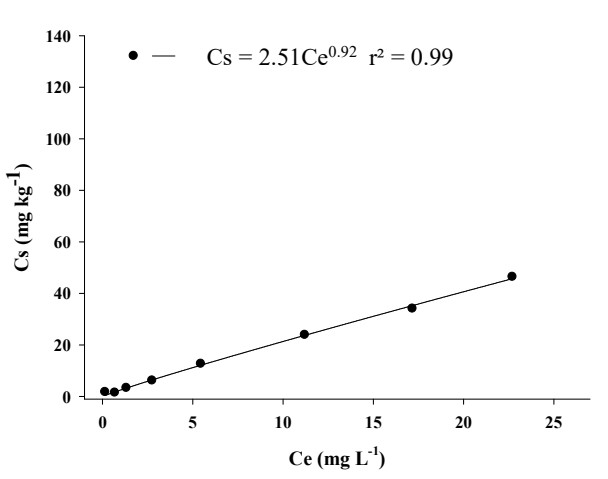

G

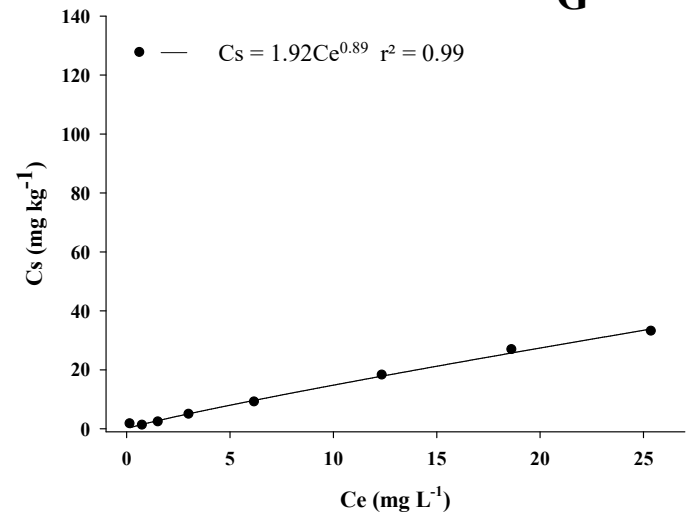

Figure 2. Estimates of ametryn sorption isotherms in: G (A), PV (B), LVA (C), LVDA (D), EKo (E), ESK $(\mathrm{F})$ and LADT $(\mathrm{G})$, as a function of equilibrium concentration $(\mathrm{Ce})$.

Another soil attribute that should be highlighted in the soils G and PV is the CEC. The high value of CEC these soils also can contribute to ametryn sorption. The ametryn is an herbicide with weak base characteristic, and the protonated molecules in the solution can blind to the negative 
charges of organic and minerals colloids, mainly when the soil $\mathrm{pH}$ value is close to $\mathrm{pKa}$ of the herbicide (FARIA et al., 2018; ASSIS et al., 2011;
ANDRADE et al., 2010). The other soils demonstrated similar sorption capacity (Table 2).

Table 2. Estimates of sorption coefficients ( Kf e $1 / n)$ and coefficients of determination $\left(R^{2}\right)$ of ametryn sorption isotherms in different soils

\begin{tabular}{llll}
\hline \multirow{2}{*}{ Soils } & \multicolumn{3}{c}{ Coefficients } \\
\cline { 2 - 4 } & Kf & $1 / \mathrm{n}$ & $\mathrm{R}^{2}$ \\
\hline G & 22.79 & 0.96 & 0.99 \\
PV & 6.42 & 0.82 & 0.99 \\
LVA & 3.38 & 0.81 & 0.99 \\
LVDA & 2.79 & 0.85 & 0.99 \\
EKo & 2.74 & 0.91 & 0.99 \\
ESK & 2.51 & 0.92 & 0.99 \\
LADT & 1.92 & 0.89 & 0.99 \\
\hline
\end{tabular}

Gleysol (G), Red Argisol (PV), Red-Yellow Latosol (LVA), Argisol Red Dystrophic Latosol (LVDA), Espodosol carbic duric (EKo), Ferrichumiluvic Espodosol (ESK), Typical Dystrophic Yellow Latosol (LADT).

The correlation was significant and positive between $\mathrm{Kf}$ and $\mathrm{CEC}$, with a linear coefficient equal to 0.8179 (Table 3). Besides, the Pearson correlation was significant and positive between $\mathrm{Kf}$ and $\mathrm{OM}$ (0.7364) for the studied soils (Table 3). These results demonstrated that the increase in the $\mathrm{OM}$ and CEC of soil linearity elevate the ametryn sorption. For other soil attributes, as clay or $\mathrm{pH}$, there was no correlation with $\mathrm{Kf}$ (Table 3). This result is different compared to the others studied that evaluating the sorption of other herbicides. In these studies, the clay is frequently associated with the higher sorption capacity of soils (DOS SANTOS et al., 2018; MENDES et al., 2017). The fact may be related to the low clay content of the Northeast Brazilian soils (Table 1). Thereby, the clay has little contribution to adsorb ametryn molecules from the soil solution.

Table 3. Correlations between soil properties and $\mathrm{Kf}$ values

\begin{tabular}{lllllll}
\hline $\begin{array}{l}\text { Soil } \\
\text { properties }\end{array}$ & $\mathrm{pH}$ & CEC & OM & Sand & Silt & Clay \\
\hline Kf & -0.3682 & $0.8179^{*}$ & $0.7364^{*}$ & -0.6416 & 0.4716 & 0.0488 \\
\hline
\end{tabular}

$\mathrm{p}$ H: Hydrogenionic potential; CEC: Cation exchange capacity; OM: Organic matter. ${ }^{*}$ Significant at 1 and $5 \%$ probability by the $\mathrm{t}$ test.

The total percentage of ametryn desorbed behaves contrary to the sorption coefficient (Figure 3 ). As verified, the soils that had the largest number of molecules returning to the soil solution were those that had the lowest values of Kf (Figure 3). Desorption is an important feature to understand the herbicide dynamics in the soil, once this process governs the return of the adsorbed herbicide to the soil solution, making them available.

The $\mathrm{G}$ demonstrated the lowest ametryn desorption, with $35.8 \%$ of the molecules returning to the solution after 36 hours. This low desorption index is justified by the high organic matter content and high CEC of this soil. Vivian et al. (2007) reported a similar behavior for ametryn in six Brazilian soils, concluding that organic matter and clay fraction were the main attributes to adsorption and desorption. The low desorption due to the high organic matter is the result of stable interactions that occur between adsorbent and adsorbate. The organic matter can promote many interactions (electrostatic and covalent blinds) that need of high energy for desorption, impairing that the ametryn return to the soils solution (MARTINI et al., 2012).

The desorption was higher for LADT compared to other treatments, with a total of $72.2 \%$ of the herbicide returning to soil solution after 36 hours. This fact indicates that the interactions between the LADT and ametryn are weak compared to other soils studied (VIVIAN et al., 2007; ANDRADE et al., 2010). Besides that, the low affinity between LADT and ametryn can be observed to evaluate the Kf value. This soil has the lowest sorption capacity, and the few molecules of herbicide absorbed by this soil were able to return to the solution. This low affinity may be related to lower organic matter and cation exchange capacity, once these attributes are responsible by the formation of high stability blinds (MARTINI et al., 2012). 

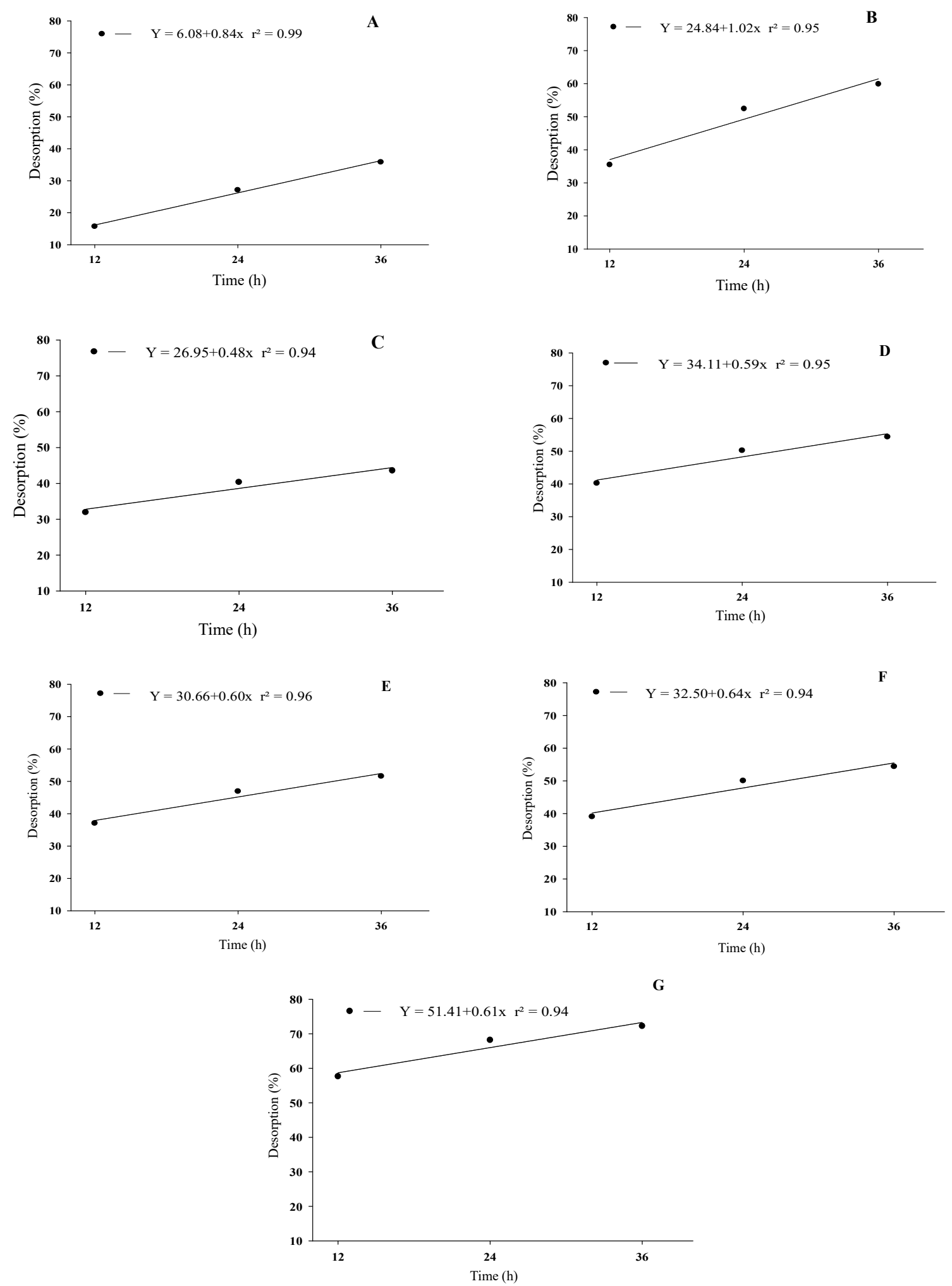

Figure 3. Percentage of ametryn desorption in soils over time: G (A), PV (B), LVa (C), LVDA (D), EKo (E), ESK (F) and LADT (G).

For the soil PV was observed a high $\mathrm{Kf}$ value, indicating a high affinity with ametryn. However, high desorption was measured for this soil
(62.0\%, Figure 3$)$. This phenomenon can occur due to the interaction types created between this soil and ametryn. Although of high organic matter and cation 
exchange capacity present in $\mathrm{PV}$, factors that increase the sorption and generally decrease the desorption, the interactions may be of low stability, initially allowing high sorption, but followed by high desorption rates (MANCUSO et al., 2011).

The results demonstrated a high variation of the sorption and desorption capacity among soils, confirming the hypotheses that for herbicide recommendations is necessary a previous evaluation about the specific behavior of ametryn in the soil. It is notorious that did not consider this fact when herbicides are recommended can increase the environmental contamination risk. Soils with low sorption capacity of ametryn or with high desorption are a pathway that may lead to the environmental contamination by higher leaching of this pollutant.
For the Brazilian Northeast regions with intensity rainfall, the low sorption of ametryn may aggravate the leaching risk of the molecule.

\section{CONCLUSIONS}

Soil physicochemical properties influence the sorption and desorption of ametryn.

Sorption was highest in soils with high organic matter content and cation exchange capacity, while desorption was inversely proportional to the sorption.

The $\mathrm{pH}$ and clay content of the Brazilian Northeast soils are less important for the ametryn sorption.

RESUMO: O conhecimento dos fatores relacionados à dinâmica de herbicidas no ambiente é de fundamental importância para prever o comportamento de herbicidas em solos com diferentes atributos e para seleção de dosagens adequadas, bem como para evitar efeitos prejudiciais ao ambiente e às culturas subsequentes. O objetivo do trabalho foi avaliar a sorção e dessorção do ametryn em sete solos com diferentes atributos. Inicialmente, foi determinado o tempo de equilíbrio pelo método "Batch Equilibrium". Em seguida foi realizado o ensaio de sorção com diferentes concentrações $\left(0,5 ; 1 ; 2 ; 4 ; 8 ; 16 ; 24\right.$ e $\left.32 \mathrm{mg} \mathrm{L}^{-1}\right)$ de ametryn em $\mathrm{CaCl}_{2}$ 0,01 mol L-1. Foram adicionadas $10 \mathrm{~mL}$ destas soluções a amostras de 2,00 $\mathrm{g}$ de cada solo, permanecendo sob agitação rotatória por 4 horas. Após centrifugação e filtração, a concentração do ametryn no sobrenadante foi determinada por cromatografia líquida de alta eficiência. A dessorção foi avaliada utilizando os tubos que continham $16 \mathrm{mg} \mathrm{L}^{-1}$ antes do ensaio de sorção. Os resultados indicaram que a sorção e a dessorção do ametryn depende dos atributos físico-químicos do solo. A sorção foi maior em solos com alto teor matéria orgânica e alta capacidade de troca iônica, enquanto que a dessorção foi inversamente proporcional à sorção.

PALAVRAS-CHAVE: Carryover. Controle químico. Herbicida. Plantas daninhas.

\section{REFERENCES}

AGROFIT. Sistema de Agrotóxicos Fitossanitários. Disponível em:

$<\mathrm{http}: / /$ agrofit.agricultura.gov.br/agrofit_cons/principal_agrofit_cons>. 15 Jan. 2019.

ALI, I.; AL-OTHMAN, Z. A.; ALWARTHAN, A. Green synthesis of functionalized iron nano particles and molecular liquid phase adsorption of ametryn from water. Journal of Molecular Liquids, Netherlands, v. 221, p. 1168-1174, 2016. https://doi.org/10.1016/j.molliq.2016.06.089.

ALBUQUERQUE, A. F.; RIBEIRO, J. S.; KUMMROW, F.; NOGUEIRA, A. J. A.; MONTAGNER, C. C.; UMBUZEIRO, G. A. Pesticides in Brazilian freshwaters: a critical review. Environmental Science: Processes \& Impacts, Switzerland, v. 18, n. 7, p. 779-787, 2016. https://doi.org/10.1039/C6EM00268D.

ANDRADE, S. R. B.; SILVA, A. A.; QUEIROS, M. E. L. R.; LIMA, C. F.; D’ANTONINO, L. Sorção e dessorção do ametryn em Aargissolo Vermelho-amarelo e latossolo vermelho-amarelo com diferentes valores de pH. Planta Daninha, Viçosa, v. 28, n. 1, p. 177-184, 2010. https://doi.org/10.1590/S010083582010000100021 
ASSIS, E. C.; SILVA, A. A.; BARBOSA, L. C.; QUEIROZ, M. E. L. R.; D'ANTONINO, L.; CRUZ, L. S. Sorption and desorption of picloram in soils under pastures in Brazil. Planta daninha, Viçosa, v. 29, n. 4, p. 893-899, 2011. https://doi.org/10.1590/S0100-83582011000400020

BOHN, T.; COCCO, E.; GOURDOL, L.; GUIGNARD, C.; HOFFMANN, L. Determination of atrazine and degradation products in Luxembourgish drinking water: origin and fate of potential endocrine-disrupting pesticides. Food Additives \& Contaminants: Part A, London, v. 28, n. 8, p. 1041-1054, 2011. https://doi.org/10.1080/19440049.2011.580012.

DOS SANTOS, L. O. G.; SOUZA, M. D. F.; DAS CHAGAS, P. S. F.; FERNANDES, B. C. C.; SILVA, T. S.; DALLABONA DOMBROSKI, J. L.; SOUZA, C. M. M.; SILVA, D. V. Effect of liming on hexazinone sorption and desorption behavior in various soils. Archives of Agronomy and Soil Science, London, p. 1-13, 2018. https://doi.org/10.1080/03650340.2018.1557323

FALONE, S. Z.; VIEIRA, E. M. Adsorção/dessorção do explosivo tetril em turfa e em argissolo vermelho amarelo. Química Nova, v. 27, n. 6, p. 849-854, 2004. https://doi.org/10.1590/S0100-40422004000600002

FAO_Food and Agriculture Organization of the United Nations_-FAOSTAT, 2017. Disponível em: http://faostat.fao.org/site/339/default.aspx. Acesso em: 15 de fev. 2019.

FARIA, A. T.; SOUZA, M. F.; DE JESUS PASSOS, A. B. R.; DA SILVA, A. A.; SILVA, D. V.; ZANUNCIO, J. C.; ROCHA, P. R. R. Tebuthiuron leaching in three Brazilian soils as affected by soil pH. Environmental Earth Sciences, England, v. 77, n. 5, p. 214, 2018. https://doi.org/10.1007/s12665-018-7285$\mathrm{x}$.

JACOMINI, A. E.; CAMARGO, P. B. D.; AVELAR, W. E.; BONATO, P. S. Determination of ametryn in river water, river sediment and bivalve mussels by liquid chromatography-tandem mass spectrometry. Journal of the Brazilian Chemical Society, São Paulo, v. 20, n. 1, p. 107-116, 2009. http://dx.doi.org/10.1590/S010350532009000100018.

JIN, X.; PELDSZUS, S. Selection of representative emerging micropollutants for drinking water treatment studies: a systematic approach. Science of the Total Environment, Barcelona, v. 414, p. 653-663, 2012. https://doi.org/10.1016/j.scitotenv.2011.11.035

MANCUSO, M.; NEGRISOLI, E.; PERIM, L. Efeito residual de herbicidas no solo ("Carryover"). Revista Brasileira de Herbicidas, Londrina, v.10, p.151-164, 2011. https://doi.org/10.7824/rbh.v10i2.106.

MARTINAZZO, R.; DICK, D. P.; HIRSCH, M. M.; LEITE, S. B.; PERALBA, M. D. C. R. Sorption of atrazine and mesotrione in oxisols and estimation of contamination potential. Química Nova, São Paulo, v. 34, n. 8, p. 1378-1384, 2011. http://dx.doi.org/10.1590/S0100-40422011000800015.

MARTINI, L. F. D.; CALDAS, S. S.; BOLZAN, C. M.; BUNDT, A. D. C.; PRIMEL, E. G.; AVILA, L A. Risco de contaminação das águas de superfície e subterrâneas por agrotóxicos recomendados para a cultura do arroz irrigado. Ciência Rural, Santa Maria, v. 42, n. 10, p. 1715-1721, 2012. https://doi.org/10.1590/S010384782012001000001

MENDES, K.; HALL, K.; SPOKAS, K.; KOSKINEN, W.; TORNISIELO, V. Evaluating agricultural management effects on alachlor availability: tillage, green manure, and biochar. Agronomy, Australia, v. 7, n. 4, p. 64, 2017. https://doi.org/10.3390/agronomy7040064.

OECD - Organization for Economic Co-operation and Development. Guidelines for testing of chemicals: adsorption-desorption using a batch equilibrium method, 106. OECD, Paris, France, 2000. 44p. 
PASSOS, A. B. R.; SOUZA, M. F.; SARAIVA, D. T.; DA SILVA, A. A.; QUEIROZ, M. E. L.; CARVALHO, F. P.; SILVA, D. V. Effects of liming and urochloa brizantha management on leaching potential of picloram. Water, Air, \& Soil Pollution, Canada, v. 230, n. 1, p. 12, 2019. https://doi.org/10.1007/s11270-018-4062-0.

UNIVERSITY OF HERTFORDSHIRE - PPDB. Pesticide properties database, 2019. Disponível em: $<\mathrm{http}: / /$ sitem.herts.ac.uk/aeru/footprint/index2.htm> 14 fev. 2019.

SCHEEL, G. L.; TARLEY, C. R. T. Feasibility of supramolecular solvent-based microextraction for simultaneous preconcentration of herbicides from natural waters with posterior determination by HPLC-DAD. Microchemical Journal, v. 133, p. 650-657, 2017. https://doi.org/10.1016/j.microc.2017.03.007

SILVA, F. C. S. Manual de análises químicas de solos, plantas e fertilizantes. 2. ed. ver. ampl-Brasília-DF. Embrapa Informação Tecnológica; Rio de Janeiro: Embrapa Solos, 2009. 626 p.

SILVA, L. O. C.; SILVA, A. A.; D’ANTONINO, L.; QUEIROZ, M. E. L. R.; LIMA, C. F.; FREITAS, F. C. L. Sorção e dessorção do ametryn em Latossolos brasileiros. Planta daninha, Viçosa, v. 30, n. 3, p. 633-640, 2012. https://doi.org/10.1590/S0100-83582012000300020

SINDICATO NACIONAL DA INDÚSTRIA DE PRODUTOS PARA DEFESA VEGETAL - SINDIVEG. O que você precisa saber sobre defensivos agrícolas, 2019. Disponível em: <http://sindiveg.org.br/sobredefensivos/>02 Abr. 2019.

STIPIČEVIĆ, S.; GALZINA, N.; UDIKOVIĆ-KOLIĆ, N.; JURINA, T.; MENDAŠ, G.; DVORŠĆAK, M.; DREVENKAR, V. Distribution of terbuthylazine and atrazine residues in crop-cultivated soil: The effect of herbicide application rate on herbicide persistence. Geoderma, Amsterdam, v. 259, p. 300-309, 2015. https://doi.org/10.1016/j.geoderma.2015.06.018.

VIVIAN, R.; GUIMARÃES, A. A.; QUEIROZ, M. E. L. R.; SILVA, A. A.; REIS, M. R.; SANTOS, J. B. Adsorção e dessorção de trifloxysulfuron-sodium e ametryn em solos brasileiros. Planta daninha, Viçosa, v. 25, n. 1, p.97-109, 2007. https://doi.org/10.1590/S0100-83582007000100011 